\title{
( Menurunkan Konsep Ontologi Mullâ Shadrâ Ke Dalam Filsafat Ketuhanan
}

\author{
Kusen \\ Fakultas Ushuluddin UIN Jakarta \\ kusen@uinjkt.ac.id
}

Abstrak: Dalam QS.18:110 terinformasikan bahwa salah satu syarat berjumpa dengan Tuhan ialah tidak melakukan kesyirikan. Dan untuk menjamin tindakan kita masuk katagori syirik atau tidak syirik niscaya berilmu. Dan ontologi Mullâ Shadrâ (Ashâlah Al-Wujûd dan Tasykîk Al-Wujûd) dapat dijadikan landasan merumuskan Taubid yang lurus, sehingga dengannya dapat diperoleh pengetahuan jaminan syirik dan tidak syirik. Dalam konteks inilah nilai penting menurunkan ontologi Mullâ Shadrâ (Ashâlah Al-Wujûd dan Tasykîk Al-Wujûd) ke dalam Filsafat Ketuhanan, yang dengannya dapat diturunkan konspsi Taubid.

\section{Kata Kunci: Ontologi, Mulla Shadra, Filsafat Ketuhanan}

\section{Pendahuluan}

\section{Karakteristik Pemikiran Mullâ Shadrâ.}

Menurut Haidar Bagir, ada sedikitnya lima aliran dalam falsafah Islậm, yaitu: 'ilm kalâm (theologi), falsafah masysyầiyyah (peripatetik), irfân (tasawuf), hikmah isyrâqiyyah (iluminasi), dan hikmah muta'âliyyah (falsafah hikmah). ${ }^{1}$ Aliran yang disebut terakhir merupakan puncak dari upaya Mullâ Shadrâ untuk memadukan seluruh aliran falsafah Islậm. ${ }^{2}$

Atas prestasi Mullâ Shadrâ memadukan beragam aliran falsafah ke dalam hikmah muta'âliyyah, Astiyani berpendapat bahwa pada saat dunia Positivisme baru beranjak maju, bersamaan itu pula dunia Islậm-Persia mencapai puncak kemajuan intelektual ${ }^{3}$. Sedangkan menurut Seyyed Mohsen Miri, hikmah muta'âliyyah dibangun dari perpaduan beragam aliran pemikiran, seperti: falsafah Yunani (khususnya Aristoteles, Neoplatonik, dan Plotinus), falsafah masysyâ'iyyah (khususnya Ibn Sînâ), ajaran irfan dari Ibn 'Arabî, wahyu, hadits, pendapat para Imam, dan ajaran hikmah isyrâqiyyah dari Suhawardî. ${ }^{4}$ Berdasarkan pemaparan tersebut di atas, kiranya dapat diambil pemahaman bahwa corak pemikran Mullâ Shadrâ terlihat pada metodenya. 
Mullâ Shadrâ berhasil menghimpun metode bayânî, metode burhânî dan metode irfânî ke dalam satu pemikiraan yang dinamakan hikmah muta'âliyyah.

\section{Ontologi Mullâ Shadrâ.}

Setiap bahasan mengenai hikmah muta'âliyyah, tidak bisa terlepas dari ajaran wujûd. Kekhasan hikmah muta'âliyyah selain terletak pada metodenya, kekhasan lainnya ada pada ajarannya, yaitu falsafah wujûd. Karena itu ketika membicarakan Mullâ Shadrâ, maka identik dengan falsafah wujûd, sehingga para pengaji falsafah Islậm menggolongkan hikmah muta'âliyyah sebagai eksistensialisme Islậm. Berikut ini gambaran singkat mengenai falsafah wujûd Mullâ Shadrâ (Ashâlah Al-Wujûd dan Tasykîk Al-Wujûd).

\section{A. Ashâlah Al-Wujûd.}

Salah satu persoalan mendasar pada ranah ontologi ialah menentukan sesuatu yang ashâlah (nyata) dan yang i'tibârî (abstrak). Dengan kata lain, apakah yang dinamakan realitas (ashâlah) itu ada pada wujûd (eksistensi) ataukah ada pada mâhiyah (esensi) ? Dan Mullâ Shadrâ adalah failusuf yang mendukung Ashâlah Al-Wujûd. Seperti yang dinyatakannya:

$$
\begin{aligned}
& \text { واننى قد كنت فى سالف الزمان شد يد الذب عن تاصل الماهية واعتبارية الوجود حتى هدانى }
\end{aligned}
$$

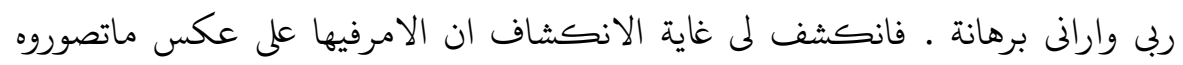

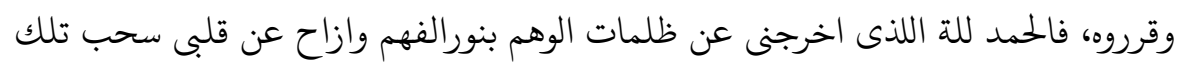

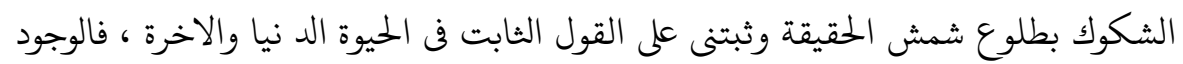

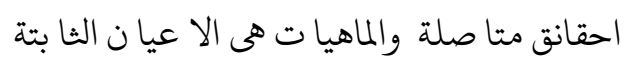

"Pada mulanya aku pendukung pendapat bahwa mâhiyah merupakan yang ashîl, sedangkan wujûd yang i'tibârî, sampai Allâh memberikan hidayah kepadaku dan membiarkanku melihat pembuktian-Nya. Mendadak mata batinku terbuka lebar dan aku melihat dengan jelas bahwa yang benar justru kebalikannya dari yang selama ini dianut oleh para failusuf. Segala puji bagi Allâh yang melalui pencerahan-Nya membawaku keluar dari ide yang tanpa dasar tersebut, dan menetapkanku pendapat yang tidak akan pernah berubah baik di dunia sekarang ini maupun kelak di akherat. Maka sekarang ini aku menganut ajaran bahwa wujûd adalah yang pokok sedangkan mâhiyah merupakan a'yân tsâbitah". 5 
Terkait Ashâlah Al-Wujûd, lebih lanjut Mullâ Shadrâ di dalam kitab alMasyầ'ir memberikan penjelesan:

$$
\text { انه (اى الوجود) الاصل الثا بت في كل موجود وهو الحقيقة , وما عداه ككس وظلوشبح }
$$

"Eksistensi adalah apa yang benar-benar ada, ia merupakan realitas sejati, dan segala sesuatu selainnya adalah cermin, bayangan, atau penyerupaan".

Untuk memahami pernyataan Mullâ Shadrâ di atas, saya memberi contoh soal "pohon". Sebuah pohon dapat dilihat dari 2 sisi:

1) Wujûd pohon itu sendiri.

2) Pemahaman kita terhadap pohon itu.

Dalam terminologi Mullâ Shadrâ, maka wujûd pohon itulah yang benar-benar realitas. Jika tidak ada wujûd pohon, maka tidak ada pula mâhiyah atau esensi pohon (konsep pohon). Itu berarti, mâhiyah atau esensi disebabkan oleh adanya wujûd. Berdasarkan hukum sebab-akibat, kedudukan sebab lebih tinggi. Jika tidak ada sebab, tidak ada pula akibat. Wujûd adalah penyebab adanya mâhiyah. Itu berarti wujûd adalah yang ashâlah (nyata) dan selainnya adalah i'tibârî (abstrak). Dalam konteks inilah kiranya dapat ditangkap makna pernyataan Mullâ Shadrâ:

$$
\text { انه (اى الوجود) الاصل الثا بت في كل موجود وهو الحقيقة , وما عداه كعكس وظلوشبح }
$$

"Eksistensi adalah apa yang benar-benar ada, ia merupakan realitas sejati, dan segala sesuatu selainnya adalah cermin, bayangan, atau penyerupaan". Pada bagian kitabnya yang lain Mullâ Shadrâ menyatakan:

$$
\text { الانسان كما يشهد فطرته بامتناع حصول الجسم الواحد في مكانين في زمان واحد }
$$

"Manusia seperti yang telah ditetapkan pada fitrah-Nya tidak mampu membuat tubuhnya yang satu berada di dua tempat pada waktu bersamaan". ${ }^{6}$

Satu tubuh manusia berada di tempat berlainan padahal waktunya bersamaan bukanlah realitas, ia hanya i'tibârî. Untuk menguatkan pandangan bahwa mâhiyah atau esensi hanyalah bayangan (cermin atau penyerupaan), dan keberadaanya tergantung dari sesuatu selain dari dirinya, Mullâ Shadrâ menyatakan: 


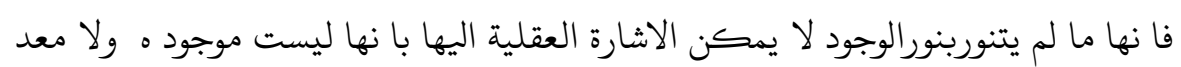

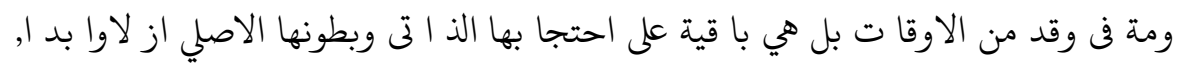

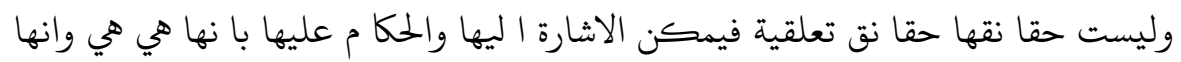

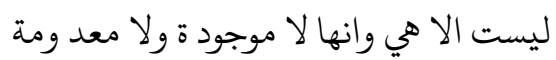

"Sesungguhnya mâhiyah-mâhiyah, selama ia tidak disinari oleh cahaya wujûd, tidaklah merupakan sesuatu yang bisa dinyatakan oleh pikiran sebagai sebagai ada atau tidak ada, ia tetap berada di dalam ketersembunyiannya yang asli dan ketidakberadaannya yang asli dan abadi, dan tidak bisa dikatakan bahwa ia adalah ia sebagaimana adanya, dan tidak selainnya" ${ }^{7}$

Berdasarkan kutipan kitab Al-Ashfâr tersebut di atas, sangat jelas jika wujûd menjadi penyebab adanya mâhiyah. Keberadaan mâhiyah tergantung dari wujûd, dan tidak sebaliknya. Terkait dengan ini Mullâ Shadrâ berpendapat bahwa wujûd tidak memerlukan wujûd lain agar ia teraktualisasi, sebab wujûd pada dirinya sendiri adalah aktualisasi itu sendiri (Al-Ashfâr II/1, 39). Itu artinya semua wujûd berasal dari wujûd. Bagaimanakah dengan wujûd alam semesta beserta seluruh isinya (termasuk wujûd manusia) ?

Jika istilah " wujûd " kita ganti dengan kata "ada", maka kiranya dapat diambil pemahaman bahwa ada adalah ada. Tidak ada adalah tidak ada. Tidak mungkin ada, sekaligus tidak ada. Sebaliknya, tidak mungkin yang tidak ada, sekaligus ada. Tiap-tiap yang ada pastilah berasal dari yang ada. Dan tidak mungkin "yang ada" berasal dari "yang tidak ada". Dengan kata lain bahwa semua yang ada pasti berasal dari yang ada juga. Begitupun keberadaan alam semesta dan seisinya (termasuk manusia) pastilah berasal dari "yang ada". Alam semesta beserta seluruh isinya (termasuk manusia) pastilah bukan berasal dari yang tidak ada. Karena yang tidak ada, tidak mungkin bisa mengadakan yang ada. Dengan kata lain bahwa keberadaan "alam semesta beserta seluruh isinya" (termasuk wujûd manusia), tidak mungkin muncul "ujug-ujug" (tiba-tiba) dari mâhiyah, karena mâhiyah itu sendiri muncul dari adanya wujûd. Tanpa ada wujûd, maka tidak ada pula mâhiyah. Itu artinya keberadaan alam semesta berasal dari wujûd. Semua wujûd berasal dari wujûd. Pertanyaannya adalah:

a) Wujûd yang bagaimanakah sehingga wujûd-wujûd lain yang beraneka ragam itu menjadi maujûd ?, atau dengan kata lain: ada yang bagaimanakah sehingga "ada-ada" yang lain menjadi berada?

b) Adanya wujûd Tuhan dan wujûd selain Tuhan, maka dimanakah letak perbedaannya ?, atau dengan kata lain: adanya keberadaan 
“Tuhan” dan adanya keberaadaan selain "Tuhan”, maka apakah ada perbedaan?

\section{B. Tasykîk Al-Wujûd.}

Tasykîk al-wujûd (ketaksaan wujûd) adalah teori Mullâ Shadrâ yang mengatakan bahwa wujûd itu bersifat tetap, namun pada saat yang bersamaan wujûd mengalami perubahan. Oleh karena wujûd memiliki dua sifat sebagaimana tersebut di atas, tasykîk al-wujûd kadang dimaknai sebagai teori kemenduaan sifat atau ambiguitas. Dalam konteks inilah wujûd dipandang sebagai sesuatu yang unik. Seperti yang dinyatkan Mullâ Shadrâ:

$$
\begin{aligned}
& \text { وان الوجود كله مع تبا ين انواعه وافرا د ه ماهيه وتخا لف اجنا سه وفصوله حد الوحقيقة, }
\end{aligned}
$$

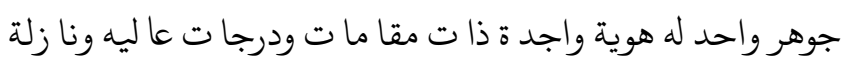

"Dan sesungguhnya wujûd adalah entitas unik yang berdiri sendiri, terlepas dari kenyataan bahwa spicies dan individu-individunya berbeda satu sama lain berkaitan dengan kuiditas, dan genus ataupun differensianya dapat dibedakan satu sama lain dalam hubungannya dengan "definisi" dan "esensi". Ia mempunyai satu aktualisasi tunggal yang memiliki tahap-tahap dan tingkatan-tingkatan yang lebih tinggi dan lebih rendah". ${ }^{8}$

Berdasarkan kutipan tersebut di atas, tampak jelas bahwa wujûd hakekatnya satu, namun wujûd memiliki keunikan. Diumpamakan sebuah Apel. Mulanya ketika belum matang, Apel berwarna hijau. Karena adanya proses pematangan, warna apel berubah jadi merah. Jika ditinjau dari sisi wujûd nya, maka Apel tersebut tidak berubah. Ia tetap Apel, namun jika ditinjau dari sisi penampakannya, Apel tersebut jelas berubah (dari hijau ke merah). Ini berarti, semua wujûd dari sisi wujûd nya adalah sama, namun jika dilihat dari sisi penampakannya wujûd mengalami perubahan.

Contoh lain misalnya air. Air gunung, air laut, air sungai, air danau, air comberan, air liur, air mani dan sebagainya, maka jika ditinjau dari keberadaannya sama. Sama-sama sebagai air. Sama-sama sebagai wujûd, namun jika ditinjau dari fenomenanya maka tampak berbeda-beda. Perbedaan jenis air satu dengan jenis air lainnya bukan disebabkan dari wujûd-nya, tetapi dari derajatnya. Derajat air gunung dengan derajat air sungai tentu berbeda. Derajat air sungai dengan air got pastilah tidak sama. Derajat air liur dengan air mani juga berbeda. Sekalipun derajatnya berbeda-beda, tetap saja semuanya sama sebagai air. Begitupun dengan wujûd Tuhan dan wujûd selain Tuhan. 
Wujûd Tuhan, wujûd malaikat, wujûd jin, wujûd manusia, wujûd pepohonan, wujûd bebatuan, wujûd air dan sebagainya adalah sama (sama-sama sebagai wujûd). Semua wujûd adalah sama. Perbedaan wujûd Tuhan, wujûd malaikat, wujûd jin, wujûd pepohonan, wujûd bebatuan, wujûd air bukanlah terletak pada wujûd-nya, tetapi terletak pada derajatnya. Atas dasar pandangan tersebut, kiranya dapat dikatakan bahwa dalam terminologi hikmah muta'âliyah, wujûd itu pada hakekatnya tunggal, namun dalam ketunggalan itu terdapat keanekaragaman atau Wahdah Al-Katsrah (kesatuan plural wujûd ). Dengan kata lain, wujûd memiliki satu makna. Di mana saja wujûd diterapkan, maka maknanya satu arti. Karena itu makna wujûd pada Tuhan, wujûd pada makhluk adalah sama. Mullâ Shadrâ menyatakan:

$$
\begin{aligned}
& \text { ومما يجب ان يعلم ان اثباتنا لمرا تب الوجودات المتكثرة, ومواضعتنا فى مراتب البحث والتعليم }
\end{aligned}
$$

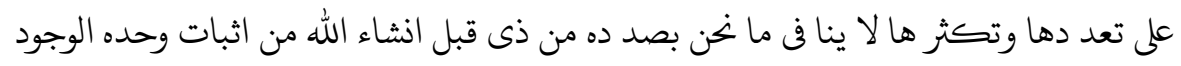

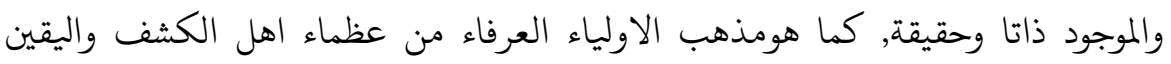

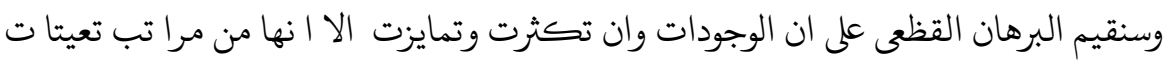

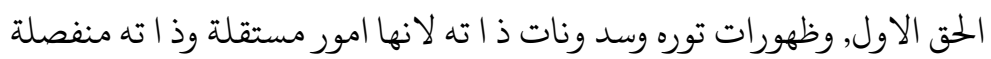

"Dan haruslah diketahui bahwa dalil yang kami sampaikan mengenai derajat eksistensi, tidaklah bertentangan dengan apa yang kami sepakati sebagaimana para pendahulu kami Insya Allâh penetapan dalil kesatuan wujûd dan wujûd -wujûd yang hakiki sebagaimana aliran para wali, urafa, ahli kasyf dan ahli agama, dan akan kami tegakkan dalil yang paling kuat bahwa wujûd meskipun terlihat banyak dan berbeda satu sama lain hanyalah dari segi derajat penampakan al-Haqq Yang Pertama dalam pemancaran cahaya-Nya dan pengejawantahan zat-Nya bukan sebagai sesuatu yang mandiri dan terpisah". ${ }^{\text {? }}$

Berdasar kutipan kitab Al-Ashfâr sebagaimana tersebut di atas, maka sangat jelas bahwa semua wujûd itu tunggal namun mengandung keragaman (wahhdah al-katsrah). Perbedaan wujûd satu dengan yang lain hanya dari segi derajat penampakanya dan masing-masing wujûd berada pada tingkat kesempurnaan yang berbeda-beda. Pertanyaannya adalah sejauh manakah perbedaan derajat wujûd Tuhan dengan wujûd-wujûd selain Tuhan?

Tingkat tertinggi dari wujûd bersifat mandiri dan sempurna, sedangkan tingkat di bawahnya semakin tak mandiri, dan tak sempurna. Secara garis besar Mullâ Shadrâ membagi wujûd menjadi 3 tingkatan (Al-Ashfâr jilid 
II, h.327-329, jilid III, 501, dan jilid IX, h.21). Ketiga tingkatan wujûd tersebut, kiranya dapat saya diskripsikan sebagai berikut:

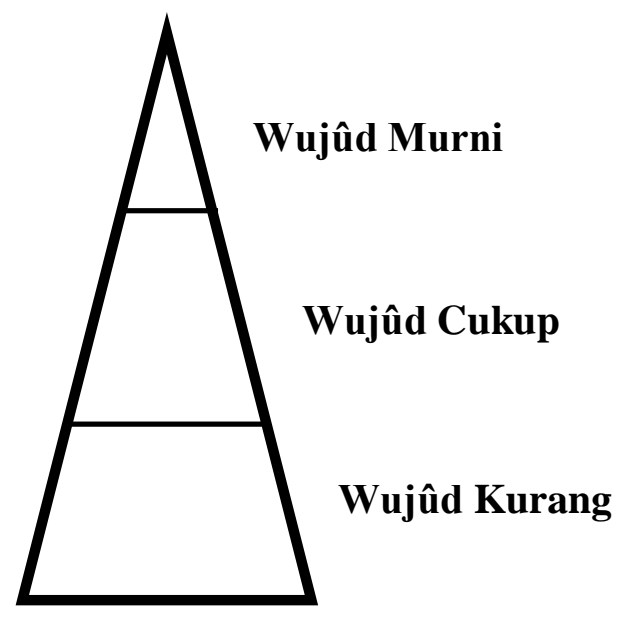

Wujûd Murni adalah wujûd yang tidak tergantung kepada selain dirinya (independen), sehingga apa saja atribut yang disematkan padanya dapat menimbulkan ketercelaan (kenegatifan), maka pastilah ia bukan Wujûd Murni. Itu artinya Wujûd Murni:

a) Tidak bergantung pada wujûd lain selain dirinya.

b) Tidak sama derajatnya dengan wujûd lain selain dirinya

c) Tidak berbilang

d) Tidak tercela sedikitpun

e) Tidak beresensi

Keberadaan Wujûd Murni dipandang sebagai Lâ Bi-Syart (keberadaaannya tanpa syarat). Wujûd Murni menjadi penyebab adanya wujûd yang lain. Jika tidak ada Wujûd Murni, maka wujûd yang lain juga menjadi tidak ada. Adanya wujûd- wujûd lain yang beraneka ragam (Wahdah AlWujûd) tergantung dari Wujûd Murni. Dalam terminologi Islam, istilah "Wujûd Murni" dapat diidentifikasikan sebagai "Tuhan".

\section{Hakekat Tuhan}

Menurut saya, tujuan tertinggi seorang muslîm adalah berjumpa dengan Tuhannya. Karena itu tujuan pendidikan Islâm juga mesti selaras dengan tujuan hidup manusia, yaitu berjumpa dengan Tuhannya. Dalam QS. 18:110 "Barang 
siapa mengharap perjumpaan dengan Tuhannya, maka hendaklah ia mengerjakan 'âmal shâlih dan jangan mempersekutukan seorangpun dalam beribadah kepada Tuhannya".

Berdasarkan informasi QS.18:110 tersebut, kiranya dapat diambil pemahaman bahwa salah satu syarat bertemu Tuhan ialah tidak berlaku syirik. Tuhan mengampuni segala dosa, kecuali syirik. ${ }^{10}$ Itu artinya mengenal hakekat Tuhan adalah keniscayaan bagi setiap muslîm agar tidak terperosok pada tindakan syirik.

Dan menurut saya, ontologi Mullâ Shadrâ dapat dijadikan landasan mengetahui hakekat Tuhan. Berdasarkan pemaparan ontologi Mullâ Shadrâ (Ashâlah Al-Wujûd, Tasykîk Al-Wujûd, Wahhdah Al-Wujûd) sebagaimana tersebut di muka, kiranya dapat diambil pemahaman bahwa menurut Mullâ Shadrâ: Tuhan adalah Wujûd Murni. Wujûd Murni adalah penyebab adanya wujûd yang lain. Jika tidak ada Wujûd Murni, maka wujûd yang lain juga menjadi tidak ada. Adanya wujûd- wujûd lain yang beraneka ragam (Wahdah Al-Wujûd) tergantung dari Wujûd Murni. Itu artinya Wujûd Murni:

1) Tidak bergantung pada wujûd lain selain dirinya.

2) Tidak sama derajatnya dengan wujûd lain selain dirinya

3) Tidak berbilang

4) Tidak tercela sedikitpun

5) Tidak beresensi

6) Tidak ber-ruang

7) Tidak terikat oleh waktu

8) Tidak tunduk pada genus dan defferentia

9) Tidak berawal dan tidak berakhir

10) Tidak beranak dan tidak diperanakkan

Keberadaan Tuhan sebagai Wujûd Murni dipandang sebagai Lâ BiSyart (keberadaaannya tanpa syarat) dan sempurna. Karena itu apa saja atribut yang disematkan padanya dapat menimbulkan ketercelaan (kenegatifan), maka pastilah ia bukan Tuhan. Dalam konteks inilah kiranya ontologi Mullâ Shadrâ dapat disebut sebagai penjelasan metode bertauhid yang paling baik.

\section{Daftar Pustaka}

Fazlur Rahman (2000). Filsafat Shadra (The Philosophy of Mulla Shadra). Terjemahan Munir A. Muin. Bandung: Pustaka. 
Haidar Bagir (2005). Buku Saku Filsafat Islam. Bandung: Mizan. , (2006). "Pengalaman Mistik dalam Filsafat Hikmah Mulla Shadra". Majalah Al-Huda. Vol.III.Nomor 9.

Hasan Abu Ammar. (2002). Akidah Syi'ah Seri Tauhid Rasionalisme dan Alam Pemikiran Filsafat Dalam Islam. Jakarta: Mulla Shadra.

Hossein Nashr, Seyyed \& Oliver Leaman (editor). (2001). History of Islamic Philosophy (part I \& II). London \& new York: Routledge. (2003). Ensiklopedi Tematis Filsafat Islam I \& II (History of Islamic Philoshopy). Terjemahan Tim penerjemah Mizan. Bandung: Mizan.

Husain Heriyanto (2003). Paradigma Holistik: Dialog Filsafat, Sains, dan Kehidupan Menurut Shadra dan Whitehead. Jakarta: Teraju.

Husein Shahab. (2000). "Filsafat Wujud dalam Wacana Para Filosuf Muslim". Al-Huda, Vol.I. No.1, 51-58.

Jalaluddin Rakhmat. (1993). "Hikmah Muta'alyyah: Madzab Filsafat Islam Pasca Ibn Rusyd”. Al-Huda, No.10, 72-80.

Khamenei, Seyyed M. (2004). Mulla Shadra's : Transcendent Philosophy. Tehran: SIPRIn Publication.

Majid Fakhry 1983. A History of Islamic Philosophy. New York: Columbia Univ. Press.

(1986). Sejarah Filsafat Islam. Terjemahan Mulyadhi Kartanegara. Jakarta: Pustaka Jaya.

Mohsen Miri, Seyyed (2004). Sang Manusia Sempurna : Antara Filsafat Islam dan Hindu. Jakarta: Teraju.

, (2002). "Mulla Shadra: Kehidupan dan Pemikirannya". Al-Huda, Vol.II, 123-150.

Muhammad Taqî Misbâh Yazdî (2003). Buku Daras Filsafat Islam. Terjemahan Musa Kazhim \& Saleh Bagir. Bandung: Mizan.

, (2004). "Gerakan Substansial, Hubungannya dengan Waktu dan

Prinsipalitas Eksistensi”. Al-Huda, Vol.III, No.10, 117-129.

Muhsin Labib. (2005). Para Filosuf: sebelum dan sesudah Mulla Shadra. Jakarta: Al-Huda.

Mulyadhi Kartanegara (2002). Panorama Filsafat Islam. Bandung: Mizan.

Murtadha Muthahhari. (2002). Filsafat Hikmah: Pengantar Pemikiran Shadra.

Terjemahan. Tim Penerjemah Mizan. Bandung: Mizan.

Musa Kazhim. (2001). "Kontroversi Seputar Akal, Hati, dan Eksistensi". AlHuda, Vol.II.No.IV, 71-90.

Mustamin al-Mandary (2003). Menuju Kesempurnaan: Persepsi Dalam Pemikiran Mulla Shadra. Makassar: Safinah. 
Shadrâ, Mullâ (1999). Al-Hikmah al-Muta'liyyah fi al-Asfâr al-'Aqliyyah al'Arba'ah. Beirut: Dâr Ihyâ wa al-Turâts al-'Arabi. , (1981). The Wisdom of The Throne (terj. J. Winston). New Jersey: Princeton University Press. , (1984). Mafâtîh al-Gaib. Teheran : The Islamic Iranian Academy of Philosophy.

, (2004). Al-Mazhâhir al- Ilâhiyyah fi Asrâr al-'Ulûm al-Kamâliyyah (terj. Irwan Kurniawan). Bandung: Pustaka Hidayah.

, (1366). Tafsîr al-Qur'ân al-Karîm. Editor Muhammad Khâwajawî. Qûm : Intisyârât Bîdâr.

, (1964). Al-Masyâ'ir. Tehran: Departement d'Iranologie Institut Franco-Iranien.

, (2001). Kearifan Puncak. Terjemahan Dimitri Mahayana. Yogyakarta: Pustaka Pelajar.

Syaifan Nur (2002). Filsafat Wujud Mulla Sadra. Yogyakarta: Pustaka Pelajar.

\section{Catatan Akhir:}

${ }^{1}$ Haidar Bagir (2005). Buku Saku Filsafat Islam. Bandung: Mizan.

2 Jalaluddin Rakhmat. (1993). "Hikmah Muta'alyyah: Madzab Filsafat Islam Pasca Ibn Rusyd”. Al-Huda, No.10, 72-80, h.73

${ }^{3}$ Mullâ Shadrâ (1571 - 1640 M) sejaman dengan Renen Descartes (1596 -1650 M).

${ }^{4}$ Mohsen Miri (2002). "Mulla Shadra: Kehidupan dan Pemikirannya". Al-Huda, Vol.II, 123-150, h. 124-125

${ }^{5}$ Mullâ Shadrâ 1964. Al-Masyầir. Tehran: Departement d'Iranologie Institut FrancoIranien,h.35.

${ }^{6}$ Al-Ashfâr I/1, h.25.

${ }^{7}$ Al-Ashfâr II/1,h. 87

${ }^{8}$ Masyầir, h4

${ }^{9} \mathrm{Al}$-Ashfâr II/1, h. 71

${ }^{10}$ Lihat QS.4: 48/116 